Canadian Journal of Educational Administration and Policy
Revue canadienne en administration et politique de l'éducation

CJEAP

\title{
A Critical Discourse Analysis of School-Based Behavioural Policies: Reconceptualizing Understandings of Responses to Student (Mis)Behaviours
}

Cara Colorado and Melanie D. Janzen

Number 195, 2021

URI: https://id.erudit.org/iderudit/1075673ar

DOI: https://doi.org/10.7202/1075673ar

See table of contents

Publisher(s)

Department of Educational Administration, University of Saskatchewan

ISSN

1207-7798 (digital)

Explore this journal

Cite this article

Colorado, C. \& Janzen, M. (2021). A Critical Discourse Analysis of School-Based Behavioural Policies: Reconceptualizing Understandings of Responses to Student (Mis)Behaviours. Canadian Journal of Educational Administration and Policy / Revue canadienne en administration et politique de l'éducation, (195),

64-78. https://doi.org/10.7202/1075673ar

\section{Article abstract}

Students who have been labeled as having "behaviour problems" in the school system have some of the worst academic and social outcomes of any student group. In most Canadian provinces, responses to students who misbehave are legislated through Safe Schools policies intended to guide districts and individual schools in responding to student misbehaviour. In this research project, we conducted a critical discourse analysis of Manitoba's Safe and Caring Schools documentation in order to analyze the ways in which provincial policies construct school-based responses to behaviours. Based on our analysis, recommendations for policy-makers to better support studentsinclude revising policies to reflect reconceptualized views of children, non-deficit understandings of behaviour, and ethical responses to student behaviour. (c) Cara Colorado, Melanie D. Janzen, 2021

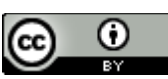

This document is protected by copyright law. Use of the services of Érudit (including reproduction) is subject to its terms and conditions, which can be viewed online.

https://apropos.erudit.org/en/users/policy-on-use/ 


\title{
A Critical Discourse Analysis of School-Based Behavioural Policies: Reconceptualizing Understandings of Responses to Student (Mis)Behaviours
}

\author{
Cara Colorado \& Melanie D. Janzen \\ University of Manitoba
}

\begin{abstract}
Students who have been labeled as having "behaviour problems" in the school system have some of the worst academic and social outcomes of any student group. In most Canadian provinces, responses to students who misbehave are legislated through Safe Schools policies intended to guide districts and individual schools in responding to student misbehaviour. In this research project, we conducted a critical discourse analysis of Manitoba's Safe and Caring Schools documentation in order to analyze the ways in which provincial policies construct school-based responses to behaviours. Based on our analysis, recommendations for policy-makers to better support students include revising policies to reflect reconceptualized views of children, non-deficit understandings of behaviour, and ethical responses to student behaviour.
\end{abstract}

Keywords: safe schools, (mis)behaviour, post-structuralism, critical discourse analysis, policy, culturally competent schools

In the last two decades, Manitoba, in line with other education jurisdictions across Canada and the United States, implemented Safe Schools legislation, which outlines responses to student misbehaviour in the school system. This legislation and its supporting documents have been implemented, in large part, as a response to concerns over bullying and school violence (Roher, 2007). However, these policies, often implemented as "zero-tolerance" policies (Winton, 2012), can further alienate those students already marginalized in the public school system, thereby exacerbating their negative schooling experiences, including lack of school success (Dufresne et al., 2010; Finlay, 2003; Rankin et al., 2013).

Since behaviour can be understood as not merely disordered conduct, but also as a form of communication, of protest, of learning or dialogue (Millei \& Petersen, 2014), we use the term (mis)behaviour, "in an attempt to signal the binaried and subjective nature of children's behaviours, and importantly, the socially constructed nature of these ideas" (Janzen \& Schwartz, 2018, p. 120). This is an ongoing reminder that often, student behaviours are deemed misbehaviours insofar as they are labeled as deviant or inconvenient by the school system (Gore \& Parkes, 2008).

Students who exhibit (mis)behaviours in the classroom continue to be at greater risk than other students of segregation, exclusion, poor academic achievement, and low graduation rates (Dufresne et al., 2010; Eber \& Nelson, 2007; Gore \& Parkes, 2008; Gresham et al., 2013; Thomas \& Loxley, 2007; Zwiefler \& DeBeers, 2003), Insofar as we know that behavioural difficulties can be effects of negative experiences, trauma, learning disabilities, and mental disorders (Gates et al., 1996; Kumperscak, 2015; Rydell, 2010), and are not simply markers of "bad kids", it is incumbent on policy-makers to ensure that 
schools policies do not further marginalize those students who may already be vulnerable. In recognition of this, there has been a recent push in Canada to make policies more progressive and supportive of both the "offender" and the "victim" (Roher, 2007; Winton, 2012).

\section{Context and Purpose: Safe Schools Policies in Manitoba}

Since the Safe Schools Charter became provincial law in Manitoba in 2004 (Legislative Assembly of Manitoba, 2004), mandating that each student be provided with a "safe and caring school environment" (Government of Manitoba, 2004b), a number of documents providing guidelines, directives, and supports to school-based Safe Schools initiatives have been created. This paper is drawn from a larger research project (Colorado, 2018) in which a critical discourse analysis was conducted of Manitoba Education's documents supporting Safe Schools legislation. The aim was to analyze critically the ways in which the discourses relating to students, (mis)behaviours, and school responses were constructed in these documents. In the present article, we will focus on the latter part of the project-school responses to student (mis)behaviours - in order to consider how provincial policies, guidelines, and directives might better support students, particularly those who are already marginalized by/within the school system. Using a post-structural lens, we will seek to identify hidden and inadvertent injustices, power structures, and prejudices in the provincial documents with regards to school-based responses to students' (mis)behaviour.

\section{Conceptual and Theoretical Framework: Poststructural Understandings of (Mis)Behaviour}

From a poststructural perspective, discourse is not merely "groups of signs referring to content or representation", but rather, discourse also invariably and inherently "reflects and generates power, serving as a mirror of particular ideologies and socially constructed norms" (Canella, 1999, p. 38). This means that "language and discourse are not transparent or neutral means for describing or analyzing the social and biological world. Rather they effectively construct, regulate and control knowledge, social relations and institutions" (Luke, 1997, p. 2). Accordingly, discourse is a reflection of "power, serving as a mirror of particular ideologies and socially constructed norms" (Canella, 1999, p. 38). It is this idea of discourse as both reflective and generative (Luke, 1997) that we take up in order to examine the ways in which normative language and universal expectations of the school system reify normative notions of students, their (mis)behaviours, and schools' responses to them.

One of the shortcomings of such an overarching normative approach to student behaviour and welfare is that student differences can come to be understood tacitly as deficiencies (Heydon \& Iannacci, 2008). Difference in this context effectively becomes pathologized, precipitating responses that seek to "cure" students of "disorders" (Thomas \& Loxley, 2007). Such a pathologization of difference becomes a "grand narrative" which tends to paint all students with a broad brush of pre-determined responses. Davies and Ellwood (2010) note that school-based responses to violence are generally based on a psychosocial model whereby both offenders and victims are understood as "deficient in social and personal skills and in need of explicit instruction in the collective ethos of the school" (p. 88).

Additionally, schools' responses to difference often endeavour to support the efficiency of the system, rather than supporting the needs and interests of the student. Callan (2011) notes that children are frequently silenced or removed as a means to maintaining order, particularly when those children are presenting either overt or subtle attacks against democratic norms. Indeed, Gore and Parkes (2008) cite multiple studies in which children who (mis)behave often receive teaching with a focus on control rather than on pedagogy or curriculum. Responding to student (mis)behaviour with consequences such as suspensions and expulsions has a negative effect because by removing the student from the environment, the school removes the student from the subsequent learning opportunities. The result is that the achievement gap for children who have been deemed as having "behaviour concerns" tend to widen over time, rather than narrow. In considering students who are deemed as "misbehaving," it is vital to examine how actions informed by the discourses within provincial legislation "can damage people unnecessarily, but also how they can be changed" (Fairclough, 2018, p. 35). 


\section{Literature Review: Framing Student (Mis)behaviour}

In the case of education policy and directives, there is ample research demonstrating how current policies may not best support children exhibiting (mis)behaviours, especially those already marginalized in schools. In what follows, we have organized the literature on student (mis)behaviour into themes of: violence-prevention, blaming the bully, and socio-economic and cultural factors to (mis)behaviour.

\section{A "Violence-Prevention" Approach and an Ideology of Risk}

In an era of increasing school violence, a focus on violence prevention has led to staff being trained to look for "risk factors" in students to pre-warn of potential dangers (Miller, 2008). Although vigilance of potential risk is important, it must also be understood that "risk factors" can frequently be symptoms of languishing mental health and therefore, "the proven fundamentals of violence prevention include strategies that are child focused and support learning" (Callahan, 2008, p. 59).Teachers, due perhaps to lack of time, training, or understanding, are often less likely to employ time-heavy responses to risk factors and are more likely to refer students to over-simplified behaviouristic responses (Davies \& Ellwood, 2010) or to employ responses that prioritize the school's need for order (Noguera et al., 2010). School actors who see themselves as managers of safety run the risk of labelling students as "dangerous" and, therefore, do not provide necessary supports (McLaughlin \& Miller, 2008).

\section{Blaming the "Bully"}

In the 1990s, zero-tolerance policies were introduced as a panacea for school safety (Bailey, 2017), intending to create safe learning environments for most children, by removing some children. While Canadian schools have distanced themselves from such policies-largely in response to research showing that such policies are detrimental to a large number of children (Dufresne et al., 2010; Roher, 2007; United Nations, 2006; Winton, 2012) - our current "policy mix still maintains punitive elements from its zero-tolerance past" (Bailey, 2017, p. 148). One of the most prominent discourses remaining from zero-tolerance policies is the discourse of the "bully" (Stein, 2003), which has shifted "the discussion of school safety away from a larger civil rights framework to one that focuses on, pathologizes, and in some cases, demonizes individual behaviour" (Stein, 2003, p. 787). Within this discourse, once a student is labelled a bully, zero-tolerance models of punishment, which often do not equally consider the rights of the "offender", are enacted (Baily, 2017).

\section{Socio-Economic and Cultural Factors of (Mis)Behaviour}

Rather than operating as a means of human liberation, the education system can serve to perpetuate social inequalities (Davis et al., 2015). In Manitoba, for example, educational outcomes for Indigenous children fall significantly behind their non-Indigenous counterparts (Auditor General of Manitoba, 2016; Lambert, 2017; Manitoba Council on Education, 2007). Additionally, students in the foster care system disadvantaged by poverty and racism are often further marginalized by school-based behaviour policies that focus on externalizing actions rather than the functions or contexts of those behaviours, and that often result in suspension or removal from classroom environments. (Callan, 2011; Noguera, 2003; Winnipeg Free Press Editorial Board, 2018). In this context, there has been a tendency to locate risk factors in socio-economic and cultural variables, wherein risk is seen as lying "not in the behavior but in the social position of those exhibiting it" (Swadener \& Lubeck, 1995, p. 28). If the education system does not consider alternate perspectives, viewpoints, or cultural norms, minority children are placed at a disadvantage from the outset and are often blamed or vilified by reacting to social conditions beyond their control; be it racism, poverty, neglect, or other contextual forces that often go unseen without consideration of the whole child. Inequality and diversity necessitate non-hierarchical relationships in education, where children and adults co-create knowledge in projects of "cultural, social, political and economic significance" (Dahlberg et al., 2007, p.7).

Normative school-based responses to difference have tended to take an assimilationist stance towards behaviour response (Callan, 2005), without accommodations for multicultural or pluralist understandings of student positioning (Baker, 2002). To equitably support all learners, learning environments must be crafted to build on culturally competent social contracts that allow children to see purpose and 
value in the classroom. Too often, the school system still operates on a modernist understanding of a social contract, which holds that children will follow the rules and relinquish personal freedoms in order to gain the benefit of an education (Noguera, 2003b). However, if children do not see school as engaging, relevant, or a means to life improvement, the social contract has broken down (Davies, 2008). (Mis)behaviour over-simplified as a momentary "choice" to obey or disobey does not allow for understandings of behaviour as expression, call for help, demonstration of agency, breakdown in shared understandings, or means of communication, which would require consideration of student positioning, not a simply behaviouristic response (Laws, 2012; Laws \& Davies, 2000).

\section{Methodology: Critical Discourse Analysis of Policy Text(s)}

Jørgensen and Phillips (2002) maintain that critical discourse analysis allows us to examine texts as social actions, since "discourse is an important form of social practice, which both reproduces and changes... identities and social relations... in specific institutions" (p. 76). Placed in our specific context, this means that discourses used in provincial policy documents have a direct influence on the social practice of individuals within the school system. Therefore, it is fundamental to examine policy texts in order to determine whose needs are (or are not) being supported by the discourses employed within them. The project employs methods in line with van Dijk's (1989) methodology, which links discourse with ideology. Van Dijk (1989) has noted that examination of discourse can serve as a consideration of ideology, insofar as the discourse is used in the practices of group members to allow for the "reproduction of... sociocultural hegemony" (p. 41). Critical discourse analysis in this iteration begins with identifying signifiers utilized in a text or texts to identify themes used within the documents, and to ascertain which ideologies are being upheld by those particular discourses. Drawing on this understanding, this study will examine the discourses in each of the identified documents as a means to uncovering the broader ideologies implicit within the documents and the potential constitutive effects of such discourses.

\section{Methods and Procedures}

In determining the documents for inclusion in the analysis, we sought documents that met the following criteria: published by Manitoba Education in support of Safe Schools legislation in Manitoba; mandated to direct, guide, or make recommendations in schools; created for educators required to enact the policies; produced in the last ten years and remain current; and intended to guide school-based responses to children's (mis)behaviours. Provincial documents that met the inclusion criteria and a description of their mandates are outlined in Table 1.

Table 1

Manitoba Education Documents Analyzed

\begin{tabular}{ll}
\hline Document: & Mandate of Document: \\
\hline Safe and Caring Schools: Taking Action & To support existing planning and policy development \\
Against Bullying - hereafter referred to as & in Manitoba by providing implementation guidelines \\
Taking Action Against Bullying (2014) & $\begin{array}{l}\text { for proactive and reactive responses to bullying in } \\
\text { schools. }\end{array}$ \\
\hline
\end{tabular}

Safe and Caring Schools: A Whole-School To provide school divisions and schools with guideApproach to Safety and Belonging - hereafter lines for implementing policies and programming foreferred to A Whole School Approach (2017) cused on school systems that support belonging, mental health, and school safety.

Safe and Caring Schools: Code of Conduct To direct school divisions and individual schools as to - hereafter referred to as Code of Conduct what they must abide by in developing codes of con(2017) duct.

Towards Inclusion: Supporting Positive Be- To provide research-based strategies and recommenhaviours in Manitoba Schools - hereafter re- dations for classroom management for school teams ferred to as Towards Inclusion (2011) and teachers.

In conducting the critical discourse analysis of $A$ Whole School Approach, Code of Conduct, Taking Action Against Bullying, and Towards Inclusion, open coding was used, reading each document three 
times, highlighting the signifiers related to the response of the school to (mis)behaviour. The collection of signifiers related to school-based responses to (mis)behaviour were then coded and sorted on the basis of themes and assumptions being made within the documents. The signifiers were then arranged into thematic categories using a spreadsheet. The categories were then examined for sub-themes in order to consider dominant ideologies upheld in the documents. After separate examinations of the discourses in each document, the documents were compared to each other to consider the similarities, differences, overlaps, and absences of discourses among them.

It is important to acknowledge that the positionality of the researchers, as in all such studies, influenced the allocation of themes used for the categorization of signifiers and also influenced the conclusions reached. Reviewing documents from a poststructuralist perspective, the readings of the documents identified management models that tend to normalize, manage, or tame behaviours as problematic, and themes were organized partly in response to those normative themes. A replication of this study may reach somewhat different conclusions, depending on the positionality of the researcher.

\section{Findings and Analysis}

In the analysis of $A$ Whole School Approach, Code of Conduct, Taking Action Against Bullying and Towards Inclusion, signifiers referencing school responses to student (mis)behaviour were collected, coded, and sorted into five discursive themes, as shown in Table 2:

Table 2

Discursive Themes Related to Responses to Children's (Mis)behaviour

Management Responses that make reference to either:

Responses (a) mandated process, documentation or legislation, including: reporting behaviour, collecting data, referring to particular mandates, reviewing policy, etc.

(b) specified particular mechanical processes intended for teachers to follow verbatim, for example: "give students at least 10 seconds to respond before repeating request" (Manitoba Education and Training, 2015a, p. 10), "make more start requests than stop requests" (Manitoba Education and Training, 2015a, p. 11), or, "ignoring students who engage in attention-seeking behaviour" (Manitoba Education and Training, 2015a, p. 54);

\begin{tabular}{ll}
\hline Restorative & Responses that seek to work together with students to "restore a sense of safety and \\
Responses & belonging" (Manitoba Education and Training, 2017a, p. 26), including collabora- \\
& tive problem solving and opportunities to work towards restitution following their \\
& actions;
\end{tabular}

Intervention Responses that follow a medicalized model of diagnosis and prescription, whereby Responses teachers refer or put in place behavioural, social-emotional, academic, or organizational interventions for students with the aim to have students "learn" acceptable behaviours or make "better" choices;

Disciplinary Responses that follow a behaviour-punishment paradigm whereby students deemed Responses as offenders are dealt with via disciplinary consequences or withdrawal

Future Planning Responses in which current behaviour data is collected not for immediate stuResponses dent-specific planning, but for long term school-wide planning and initiatives with the goal of producing a safe school environment.

Following this analysis of signifiers and phrases discussing school responses to (mis)behaviour, the verbs used to describe school responses to (mis)behaviour as signifiers of the actions taken on/for/with students were collected, coded and sorted into the five categories (Table 2). 
Table 3

Verbs Used to Describe School-based Responses to (Mis)behaviour

\begin{tabular}{|c|c|c|c|c|}
\hline $\begin{array}{l}\text { Management } \\
\text { Responses }\end{array}$ & $\begin{array}{l}\text { Intervention } \\
\text { Responses }\end{array}$ & $\begin{array}{l}\text { Restorative } \\
\text { Responses }\end{array}$ & $\begin{array}{l}\text { Future Planning } \\
\text { Responses }\end{array}$ & $\begin{array}{l}\text { Disciplinary Re- } \\
\text { sponses }\end{array}$ \\
\hline Address & Adapt & Adjust & Adjust & Consider \\
\hline Apply & Ask & Encourage & Ask & Deal \\
\hline Collect & Assist & Hold & Create & Detain \\
\hline Confirm & Build & Reach & Develop & Expel \\
\hline Consider & Communicate & Respond & Explore & Ignore \\
\hline Contact & Create & Restore & Generate & Identify \\
\hline Define & De-escalate & Support & Identify & Pause \\
\hline Emphasize & Defuse & & Look & Modify \\
\hline Engage & Demonstrate & & Organize & Move \\
\hline Ensure & Describe & & Plan & Owe \\
\hline Establish & Discuss & & Try & Protect \\
\hline Find & Facilitate & & Work & Redirect \\
\hline Follow & Give & & Understand & Remove \\
\hline Identify & Help & & & Require \\
\hline Include & Move & & & Respond \\
\hline Introduce & Remain & & & Suspend \\
\hline Notify & Make & & & Use \\
\hline Offer & Reinforce & & & Wait \\
\hline Organize & Teach & & & Withhold \\
\hline Outline & Provide & & & Withdraw \\
\hline \multicolumn{5}{|l|}{ Prescribe } \\
\hline \multicolumn{5}{|l|}{ Provide } \\
\hline \multicolumn{5}{|l|}{ Receive } \\
\hline \multicolumn{5}{|l|}{ Recognize } \\
\hline \multicolumn{5}{|l|}{ Reduce } \\
\hline \multicolumn{5}{|l|}{ Report } \\
\hline \multicolumn{5}{|l|}{ Require } \\
\hline \multicolumn{5}{|l|}{ Respond } \\
\hline \multicolumn{5}{|l|}{ Restate } \\
\hline Understand & & & & \\
\hline
\end{tabular}

\section{Primary Discursive Theme: A Management Response}

In three of the four documents, specifically, Taking Action Against Bullying, Code of Conduct, and Towards Inclusion, the primary discursive theme surrounding responses to student (mis)behaviour is a management response. In Taking Action Against Bullying, for example, the most frequently noted response to (mis)behaviour is simply reporting it. The word "report" is used 14 times in the nine-page document, including, "what to report, when to report" (p. 1) and to whom to report it. This idea of reporting-as-response is problematic. If educators see it "as their duty merely to seek out, reveal and measure [exceptionalities] rather than explicate them or problematize them" (Thomas \& Loxley, 2007, p. 24), then we are simply identifying non-compliant or non-normative behaviours rather than providing supports or alternative responses to students.

Management responses are also seen in the Code of Conduct, which prescribes a continuum of "appropriate interventions and disciplinary consequences" (p. 1) for (mis)behaviour. These interventions and consequences include: parental involvement, meeting with a school counselor or resource teacher, conducting a formal interview, withdrawing a student from the classroom setting, removing student privileges, detention, implementing a behavioural contract, conducting a threat assessment, notifying 
the police, suspension and expulsion (p. 6). The document frames consequences as a sequential list of low-intensity to high-intensity responses, implying that if a student chooses to continue with (mis) behaviour, increasingly severe consequences ought to be administered. This "treatment" modality, in which an amplified dualism of choice and consequence is enforced, assumes that (mis)behaviour is internally situated within the child, obscuring the ways in which these (mis)behaviours may be influenced by social circumstances (Laws \& Davies, 2000). Solely implementing a hierarchical, systematized, management approach in response to student actions cannot consider these social circumstances.

This primary emphasis on management responses to (mis)behaviour is also seen in Towards Inclusion, which provides guidelines for teachers to follow. (See Table 4).

Table 4

Signifiers for Responses to (Mis)behaviour in Towards Inclusion

\begin{tabular}{|c|c|}
\hline Themes & Signifiers \\
\hline $\begin{array}{l}\text { Staff protocols } \\
\text { intended to provide } \\
\text { instruction on how } \\
\text { school systems triage } \\
\text { behaviour }\end{array}$ & $\begin{array}{l}\text { - quickly deal with problems } \\
\text { follow through on agreed-upon office referral protocols so that } \\
\text { individual problem behaviour is dealt with fairly, consistently, and } \\
\text { promptly } \\
\text { develop consensus among the whole school staff to determine when } \\
\text { it is appropriate to send a student to the office }\end{array}$ \\
\hline $\begin{array}{l}\text { Systematic advice } \\
\text { regarding response to } \\
\text { student (mis)be- } \\
\text { haviour }\end{array}$ & $\begin{array}{l}\text { - } \text { move close to students when giving directions } \\
\text { give students at least ten seconds to respond before repeating the } \\
\text { request } \\
\text { - } \quad \text { ask only twice, then follow-through with a correction } \\
\text { - } \quad \text { make moin calm and unemotional } \\
\text { make start requests than stop requests }\end{array}$ \\
\hline $\begin{array}{l}\text { Clear definitions of } \\
\text { cause-and-effect be- } \\
\text { haviour responses }\end{array}$ & $\begin{array}{l}\text { - establish consequences to inappropriate behaviours ahead of time. } \\
\text { For example, owing time at recess... withholding a privilege, re-or- } \\
\text { ganizing a seating plan } \\
\text { some students who misbehave need a time out-a short break from } \\
\text { class activities before rejoining the group }\end{array}$ \\
\hline
\end{tabular}

Towards Inclusion lists relationship building, listening, and getting to know students, not as a means to learn about, support, or engage in productive relationships with students, but rather as a means to foster control of students. Indeed, the management focus of Towards Inclusion is problematically prescriptive in some places and offers conflicting advice for teachers. For example, the document suggests offering "a specific verbal response," but then notes that "tone of voice can escalate... a situation." Later, it indicates that "both verbal and nonverbal feedback are effective responses to problem behaviour," but in general, "when possible, use actions rather than words." It also states that "touch," "eye contact," "ignoring," "using the student's name," and "providing feedback without the use of names" are all methods of responding to (mis)behaviour. The sheer number of directions and the tendency for these directions to conflict demonstrates the downsides to imperatively worded policies, specifically, the foreclosure of possibilities for interpretation, individual judgement, or creative pedagogy.

A Whole School Approach is unique among the documents studied in that its primary purpose is to assist school leadership teams in planning for (future) school safety and belonging, rather than to respond to immediate risks or incidents. The document discusses: "identifying priorities and focusing resources to implement practices that have an impact on school safety" (p. 17), "planning for a continuum of proactive and responsive strategies" (p. 23), and "collaborative planning [where] focused, solutions are found, and roles and responsibilities are defined within the identified systems.... to address identified risk factors include developing positive relationships, facilitating connections and a sense of community, building strengths and supporting resiliency" (p. 27). Utilizing the verbs, "develop," "plan," "create," "explore," and "work," the document focuses on using current data to make changes to the school environment with the goal of supporting students. This broader perspective of planning for inclusion is a positive one and provokes the reader to wonder why this "planning for student success" paradigm is absent from the other 
documents.

\section{Secondary Discursive Themes: Disciplinary and Interventionist Responses}

Student-focused discourses are noticeably absent in Taking Action Against Bullying, Code of Conduct, and Towards Inclusion. Taking Action Against Bullying advises management-via-reporting solely so that students can be referred on to disciplinary responses - the only other discursive theme used in this document. There are no mentions of restorative responses, planning responses, or even interventionist responses in the document. It is noteworthy that Taking Action Against Bullying is unique in the four documents examined, as parents are listed as a primary audience for this document, and as such, it tends to read as a kind of promise to parents that bullying is being taken seriously in schools.

Code of Conduct and Towards Inclusion have intervention responses as their secondary discourses. For example, the Code of Conduct suggests that school teams "discuss the student's specific behaviour and the steps that must be undertaken to change it," "meet with the student with the specific goal of developing a plan for changing attitudes," or "develop a plan to change the student's behaviour" (p. 6). In some cases, the intervention seems to be phrased as discipline; for example, "[the] student is required to meet specific behavioural standards in order to avoid more severe consequences" (p. 6). In other cases, it appears as a medical intervention: "a referral may be made to school division student services personnel who can assist school personnel in the remediation of inappropriate behaviour" (p. 7). The word "remediation" is an interesting one here, since remediation, "the giving of remedial teaching or therapy" (Oxford English Dictionary, 2018) draws on the idea of a cure for (mis)behaviour, which constructs the (mis)behaviour as that of a "malady" which can then be cured with appropriate "treatment."

This idea of (mis)behaviour as something to be remedied is reflective of the multitude of disciplinary responses in the Code of Conduct, attempting to "hold students accountable for unacceptable behaviour" (p. 1). The document begins with some more progressive ideas noting that, "negative consequences may be necessary when other approaches to problem behaviour are unsuccessful, however, they are not effective when over-used" (p. 7, emphasis added); and that "consequences... emphasize positive and proactive strategies that foster student learning, as opposed to punitive and reactive strategies (p. 5). However, the document goes on to specify that, "student[s] [are] required to meet specific behavioural standards in order to avoid more severe consequences" (p. 6). This understanding of (mis)behaviour-as-malady requiring treatment of either: (a) a consequence or (b) re-teaching does not consider the social complexities of human behaviour.

Code of Conduct's declaration that, "reasonable accommodation is required for students with exceptional learning needs that affect their behaviour" (Manitoba Education \& Training, 2017b, p. 5) is noteworthy insofar as it seems problematic to hold only learning needs (worded as "state of development" earlier in the document) as sole considerations to inform interventions or consequences. For example, we might also focus on considerations of student trauma, perspectival realities, socio-economic disparities, family breakdown, and experiences of violence and/or substance abuse in informing decisions about responses to (mis)behaviour. Additionally, we might consider that the possibility of perceived injustices inflicted on the student by the school itself might lead to (mis)behaviour and thus, (mis)behaviour might actually be just protest. Therefore, rather than solely considering the frequency and intensity of (mis) behaviours, school personnel ought to also consider the intent, purpose, and the subjugated position of the student.

Towards Inclusion also utilizes intervention-based discourses. For example, the document states that a "continuum of increasingly intense interventions" should be used (p. 4) and that "some students... require individualized approaches that include proactive and reactive strategies" (p. 34). Notably, Towards Inclusion's discussion of interventionist responses include one of the few references to including parents in any response to (mis)behaviour, noting, "a behavioural change planning process helps to identify, monitor, and improve the classroom behaviour of your students, and provide a way for parents and school staff to communicate regularly" (p. 62). This seems to reflect teacher-based perspectives, which sees teachers acting with children and parents, rather than on children and parents.

A Whole School Approach diverges from an over-emphasis on management, interventionist, and disciplinary themes present in the other documents. It more fully explores restorative responses; that is, responses to (mis)behaviour that consider the needs of both the "offender" and the "victim". Restorative responses are not included in Towards Inclusion and Taking Action Against Bullying and Code of 
Conduct, contain only one (identical) sentence noting that, "many schools have successfully introduced responsive/ restorative practices that aim to develop community and manage conflict and tensions by repairing harm and building relationships" (Manitoba Education, 2017b, p. 4; Manitoba Education \& Training, 2014, p. 6). This statement, while conceding the availability of restorative approaches, does not indicate how educators should (or could) be using them. A Whole School Approach, however, includes at least four statements referring to restorative practices, for example, "responding through restorative practices [to] engage children, families, educators, schools and the communities in meaningful, solution-focused, disciplinary and responsive practices" (p. 30). While restorative responses focus on solution-focused planning with students, rather than punitive responses placed on students, it nonetheless remains problematic that restorative justice, which originated in the criminal justice system (used with adults, convicted criminals) is being transposed into the school system at all.

Furthermore, despite the fact that $A$ Whole School Approach is not a document intended to respond to "bullying," at times, the term "bullying" seems to be used interchangeably to describe unsafe behaviours or (mis)behaviours; thus, conflating the discourses of "safety" and "bullying." For example, the document stipulates that, "the goal of secondary-tier planning is to identify children and youth experiencing or exhibiting recurring bullying-involved behaviours", whereupon in the next sentence, it notes that, "planned interventions at the secondary tier interrupt the potential for incidents to escalate and further affect student and/ or school safety and success" (Manitoba Education \& Training, 2017a, p. 22). This discourse seems to position bullying as any action that threatens school safety, rather than as a complex set of social actions within particular contexts.

A Whole School Approach advocates for the utilization of a "continuum of identified needs and interventions" (p. 30) but seems to allow for intervention models that are more student-focused, which "may include continued work toward increasing children self-awareness, strengthening support networks, and increasing protective factors to decrease the potential for further crisis and/or to attend to chronic needs" (p. 29). In this way, $A$ Whole School Approach employs a continuum of responses that attempt to consider student need or student situatedness, rather than solely institutional convenience or a checklist response to (mis)behaviour. However, without more focus on student voice, participation, and context, there is a persisting concern that the school may not have a clear sense of the particular concerns, subjectivities and contexts for each student. These one-size-fits-all approaches run the risk of negating the particularities of students and undermine the necessary judgement required for schools to respond to students' (mis) behaviours.

\section{Summary of Discursive Themes in Responding to (Mis)Behaviour}

The four documents analyzed respond to student (mis)behaviour in disciplinary and reactive ways, often with actions being implemented $o n$ rather than with children, and in some cases, are overly prescriptive. While $A$ Whole School Approach seems to make an attempt to: value belonging, see (mis)behaviour as a need rather than defiance, and value relationships with students, the other three documents do not engage with these discourses at all, let alone prioritize them. In fact, the multitude of perspectives and underlying assumptions about children, their (mis)behaviours, and the schools' responses to them illustrate the numerous and often discordant theories and approaches underpinning these documents.

\section{Discussion: Re-Invisioning Policy}

One of the most apparent deficiencies of the four documents examined is that they are poorly aligned in regard to ideology. School teams-via A Whole School Approach-are asked to prioritize safety and to value belonging (as defined by restorative justice); teachers - via Towards Inclusion-are to be implementing a management model in responding to (mis)behaviour; administrators-via Code of Conduct-are charged with enacting a disciplinary model in responding to (mis)behaviour; and parents-via Taking Action Against Bullying - are being assured of schools' zero-tolerance approaches. The lack of common values and approaches results in competing beliefs, fractured purposes, and inconsistent tactics for understanding students and engaging with them. The result is that important guiding values such as inclusion, civil rights, and belonging risk sounding like an after-thought to the policy guidelines. If the goal is to guide educators through policy directives that uphold common guiding principles, this commonality is absent. In this vein, considerations of children's dignity and rights, which have not been included as guid- 
ing values, ought to be a prominent theoretical underpinning. To accomplish this, reconceptualized views of children, including consideration of children's perspectives and rights, non-deficit understandings of behaviour, and ethical responses to (mis)behaviour must inform policy documents.

\section{Reconceptualizing Children's Perspectives and Children's Rights}

Lesko (1996) has argued that positioning children as residing in a liminal state on their way towards adulthood has resulted in an understanding of children as not-yet-developed, and as not worthy of our time and attention. Wall (2008), in line with the 1989 United Nation's Convention on the Rights of the Child notes, "children too can be granted, on this perspective, a basic set of rights to be treated with dignity and respect" (p. 134). Swadener et al. (2013) outline, for example, how ethical consideration of children's rights can be embraced as an evolution: moving away from deciding on behalf of children, to listening to children, to taking children's views into account, and to sharing decision-making powers with children. Manitoba Education, in its role mandating, supporting and guiding policy implementation, must position schools and their personnel as working ethically alongside the children they serve.

\section{Strength-Based Framing of Behaviour}

One facet to employing strength-based perspectives would be to reconsider the simplistic discourses of bulling and safety. Walton (2005) notes that the "implication... that good kids don't bully, bad ones do; and that research-based solutions [are] in large part implicitly predicated on rooting out the bullies, like pulling noxious weeds from an otherwise aesthetically pleasing garden" (p. 59) is counter-productive to supporting students and safe schools alike. He maintains, "bullying [is] a discursive invention, employed and deployed by researchers, parents, educators and youth service providers, which contains and appears to make manageable a particular subset of violence that seems otherwise uncontainable and out of control" (Walton, 2005, p. 62). Indeed, safety and bullying are used interchangeably in the documents examined in this study, and Manitoba's overly-broad definition of bullying allows for a multitude of behaviours to be constructed and/or dismissed as bullying-behaviours, and thus, are met with over-simplified behaviouristic and disciplinary responses. Given that "the proliferation of policies and programs purported to reduce bullying in schools are anchored by what appears to be a common, but problematic, understanding of the notion of bullying" (Walton, 2004, p. 91), it is vital to ensure that Manitoba's focus on the discourses of the bully and of bullying allows for non-deficit responses for all students. Indeed, as Callan (2005) has noted, we cannot lose sight of the fact that our role as an education system in supporting positive youth development should not be conflated with that of the justice system by simply handing out sentences in lieu of offering necessary supports. Over-reliance on the "bully" narrative must be carefully examined in all provincial documents to ensure that responses to (mis)behaviour serve to support all students. Framing behaviour in this way does not allow for understandings of behaviour as communication, behaviour as protest, behaviour as information to the school team, or behaviour as a symptom of trauma, for example (Davies, 2008).

In addition to the rhetoric of bullying, policy makers need to critically consider what we perceive as an over-reliance on restitution and restorative practices. In moving away from zero-tolerance policies, the documents examined seem to have over-emphasized restitution-based responses. Other considerations might include: (a) positive youth development models, such as the one put forward by Brendtro et al. (2005), who argue that schools need to move away from identifying deficits to supporting children's unique strengths to foster resiliency and restoration; (b) ethics of care, stemming from Noddings' (2002) argument that caring about others is a fundamental part of a moral society, which "occurs within ongoing face-to-face relationships, where one focuses attention intensely, experiences the issues, sees the consequences and understands how one's caring affects others" (Shevalier \& McKenzie, 2012, p. 1089); (c) the UN's Convention on the Rights of the Child, fostering discussions of what we owe children rather than what children ought to make right; or (d) ethical considerations, like Todd's (2003a), who argues that often in learning about the other, we are negligent in learning from the other, and that any ethical interaction between an educator and a child must based on relationships. Manitoba Education and Training has positioned restorative responses as the solution to punitive responses while overlooking the possibilities of strengths-based responses. 


\section{Ethical Responses to (Mis)behaviour}

Todd (2003a) maintains that teaching responsibly means teaching responsively, so we must consider ways to engage with students, educators, policymakers, and other stakeholders in an ethical manner. All four documents examined have fallen short in their recognition of the diverse student population, including diversity related to linguistic, ethnic, racial, socio-economic, gender, and sexual orientation differences. Moreover, there is little overt recognition of the importance of and Manitoba's dedication to supporting Indigenous children (Manitoba Education \& Training, 2018b). Given Hare and Pidgeon's (2011) assertion that, "Indigenous youth confront racism on a regular basis in their school encounters with peers and teachers" (p. 94), and statistics showing that Indigenous children are vastly over-represented in school-based disciplinary responses and in the criminal justice system (Winnipeg Free Press, 1997; Schick \& St. Denis, 2007), it is surprising that the considered documents contain so few references devoted to supporting culturally competent and reflective schools. Indeed, the most culturally reflective of the four documents, A Whole School of Approach, states in the preamble that it supports Manitoba's philosophy of inclusion, Manitoba's commitment to education for sustainability, Manitoba's legislation related to Safe Schools, and Manitoba's commitment to anti-bullying campaigns (p. 7-11). However, it does not overtly state the importance of schools being culturally responsive despite recent Manitoba Education and Training mandates to "bring together First Nations and non-First Nations people and foster a spirit of cooperation, understanding, and action" (Manitoba Education \& Training, 2018b, p. 3). Given the ethical responsibilities of governments and educators to uphold the Truth and Reconciliation Commission's (2015) Calls to Action, Manitoba's legislated responses to children and their behaviours need to better understand and advocate for marginalized children in our education system. Brendtro et al. (2005) note that in recent decades there has been an overabundance of deficit approaches to working with "troubled" children, which have focused on a medicalized model of diagnosing the problem-either in the child their self, or else in their near environment - and then prescribing a treatment plan to help caregivers remedy that problem. This paradigm of pathology remains salient in the four examined documents.

\section{Recommendations}

As a result of this critical discourse analysis of A Whole School Approach, Code of Conduct, Taking Action Against Bullying, and Towards Inclusion, we offer the following recommendations for education policy-makers, regarding documentation related to children's (mis)behaviour in the school system:

1. Engage in a literature review and develop a shared vision for responses to children's (mis)behaviours in the school system informed by:

a. reconceptualized views of children, children's perspectives and children's rights that move away from normative, subjective models of understanding children; and that consider students as co-creators in their learning, cultures, and identities;

b. understandings of inclusive schooling meant for all learners;

c. strengths-based views of students' behaviours, including behaviour-as-communication, behaviour-as-advocacy or behaviour-as-learning; and

d. understandings of productive relationships and cultural responsiveness, rather than simply management responses.

2. Using reconceptualized understandings of responses to children's (mis)behaviours to align provincial documentation so that they include:

a. underpinnings of non-deficit, strengths-based understandings of children and responses to their behaviours;

b. consideration of children's dignity and children's rights as guiding principles;

c. relationship-based approaches to engaging with all children, and particularly with marginalized children;

d. culturally relevant schooling, curriculum, and pedagogy;

e. language and actions that reflect children's participation in decisions being made about them (as per the UNCRC) and thus emphasizing working and planning with students in productive relationships; and 
f. more nuanced definitions of bullying and bullying responses to consider perspectival realities of both "offender" and "victim", or perhaps divorcing from the bully narrative completely, with an emphasis on strength-based perspectives.

Given the diversity in Manitoban schools and statistics that indicate the failures of the school system in supporting marginalized learners, it is necessary that policymakers engage in an active review and revision of policies in regards to how schools respond to students' behaviours.

\section{Conclusion}

The language that has been used in responding to children in the school system risks positioning children and their (mis)behaviours in ways that blame and vilify students. This language often reflects particular ideologies that circulate through policy and construct children's identities, and in turn, the schools' responses to who they are and how they behave. In this sense, it is paramount to consider the discourses inherent in provincial legislation and corresponding documents to ensure that the discourses foster: (a) the dignity and integrity of students, as well as their growth, belonging, and learning; (b) nuanced understandings of (mis)behaviour; and (c) a school system that understands and cares for a diverse student population. However, this research has found that the policy documents analyzed often construct children in terms of deficiencies, with the schools' responses scripted accordingly in the language of disciplinary action or interventionist approaches. Janzen and Schwartz (2018) argue that "regulating, rejecting, or attempting to 'remedy' some children's identities, (mis)behaviours, and ways of being in the world, makes attending to power within schools an ethical issue" (p. 120). This requires that educators and policymakers consider the school system's potential complicity in a child's (mis)behaviour, including non-responsive curriculum, poor pedagogy, and rules that require conformity rather than supporting difference. Rather than focus on remedying students, it is fundamental that legislation, policy, and guiding documents are aligned with reconceptualized understandings of children and ethical responses to their (mis)behaviours. This study has found that there is much work to be done in our provincial documentation regarding student (mis)behaviour.

\section{References}

Auditor General of Manitoba. (2016). Improving educational outcomes for kindergarten to grade 12 Aboriginal students. https://digitalcollection.gov.mb.ca/awweb/pdfopener?smd=1\&$\mathrm{did}=24817 \& \mathrm{md}=1$

Baker, B. (2002). The hunt for disability: The new eugenics and the normalization of school children. Teachers' College Record, 104(4), 663-703.

Bailey, J. (2017). From "zero tolerance" to "safe and accepting": Surveillance and equality in the evolution of Ontario education law and policy. Education Law Journal, 26(2), 147-180.

Brendtro, L., Brokenleg, M., \& VanBockern, S. (2005). The circle of courage and positive psychology. Reclaiming Children and Youth, 14(3), 130-136.

Bully. (n.d.). In Oxford English Dictionary. Retrieved June 14, 2019 from https://en.oxforddictionaries.com /definition/bully

Callahan, C. (2008). Threat assessment in school violence. In J. R. McLaughlin \& T. W. Miller (Eds.), School violence and primary prevention (pp. 59-77). Springer.

Callan, E. (2011). When to shut students up: Civility, silencing and free speech. Theory and Research in Action, 9(1), 3-22.

Camodeca, M., \& Goossens, F. (2004). Aggression, social cognitions, anger, and sadness in bullies and victims. Journal of Child Psychology and Psychiatry, 46(2), 186-197

Cannella, G. S. (1999). The scientific discourse of education: Predetermining the lives of Others: Foucault, education, and children. Contemporary Issues in Early Childhood, 1(1), 36-44.

Christenson, L. (2012). The classroom to prison pipeline. Rethinking Schools, 26(2), 1-2.

Cole, N. L. (2018). Understanding the school-to-prison pipeline. thoughtco.com/school-to-prison-pipeline-4136170

Colorado, C. (2018). A critical discourse analysis of Manitoba's safe schools documentation and implications for students (Unpublished master's thesis). University of Manitoba. http://hdl. handle.net/1993/33688 
Dahlberg, G., Moss, P., \& Pence, A. (2007). Beyond quality in early childhood education and care: Languages of evaluation (2nd ed.). Routledge.

Davies, B. (2008). Re-thinking "behavior" in terms of positioning and the ethics of responsibility. In A. M. Phelan \& J. Sumsion (Eds.), Critical readings in teacher education: Provoking absences (pp. 173-186). Sense Publishers.

Davies, B., \& Ellwood, C. (2010). Violence and the moral order in contemporary schooling: A discursive analysis. Qualitative Research in Psychology, 7(2), 85-98.

Davis, B., Sumara, D., \& Luce-Kapler, R. (2015). Engaging minds: Cultures of education and practices of teaching (3rd ed.). Routledge.

Dufresne, A., Hillman, A., Carson, C., \& Kramer, T. (2010). Teaching discipline: A toolkit for educators on positive alternatives to out of school suspensions. http://www.ctvoices.org/ publications/teaching-discipline-toolkit-educators-positive-alternatives-out-school-suspensions

Eber, L., \& Nelson, C. M. (1997). School-based wraparound planning: Integrating services for students with emotional and behavioral needs. American Journal of Orthopsychiatry, 67(3), 385-395.

Fairclough, N. (2018). CDA as dialectical reasoning. In J. Flowerdew \& J. E. Richardson, (Eds.), Routledge handbook of critical discourse studies (pp. 35-51). Routledge.

Finlay, J. (2003). Crossover kids: Care to custody. Office of Child and Family Service Advocacy.

Gates, B., Wray, J., \& Newell, R. (1996). Challenging behaviour in children with learning disabilities. UNSW British Journal of Nursing, 5(19), 1189-1194.

Gore, J., \& Parkes, R. (2008). On the mistreatment of management. In A. M. Phelan \& J. Sumsion (Eds.), Critical readings in teacher education: Provoking absences (pp. 45-60). Sense Publishers.

Government of Manitoba. (2004a). The public schools amendment act (Appropriate Educational Programming). https://web2.gov.mb.ca/bills/38-2/index.php

Government of Manitoba. (2004b). The public schools amendment act (The Safe Schools Charter). https://web2.gov.mb.ca/bills/38-2/b030e.php

Gresham, F., Hunter, K., Corwin, E., \& Fischer, A. (2013). Screening, assessment, treatment, and outcome evaluation of behavioral difficulties in an RTI model. Exceptionality, 21(1), 1933.

Heydon, R., \& Iannacci, L. (2008). Early childhood curricula and the de-pathologizing of childhood. University of Toronto Press.

Janzen, M. D., \& Schwartz, K. (2018). Behaving badly: Critiquing the discourses of "chidren" and their (mis)behaviours. McGill Journal of Education. 53(1), 109-127.

Jørgensen, M., \& Phillips, L. (2002). Discourse analysis as theory and method. Sage Publishers.

Kumperscak H. G. (2015). Aggressive behaviour in children and adolescents as a possible symptom of different mental disorders. UNSW Zdravniški Vestnik, 83(12), 872-880.

Lambert, S. (2018, January 11). Manitoba judges to hold meeting with Indigenous leaders to improve justice system. The Globe and Mail. https://www.theglobeandmail.com/news/ national/manitoba-judges-to-hold-meeting-with-indigenous-leaders-to-improve-justice-system/article36759903/

Laws, C. (2012). The bad: Being positioned as bad and counteracting that positioning. In B.

Davies (Ed.), Poststructuralism at work with marginalized children (pp. 71-91). Bentham Science Publishers.

Laws, C. \& Davies, B. (2000). Poststructuralist theory in practice: Working with'behaviourally disturbed' children. International Journal of Qualitative Studies in Education, 13(3), 205221.

Legislative Assembly of Manitoba. (2003 - 2004). The safe schools charter (c. C-38-2). https:// web2.gov.mb.ca/bills/38-2/b030e.php

Lesko, N. (1996). Denaturalizing adolescence: The politics of contemporary representations. Youth and Society, 28(2), 139-161. 
Luke, A. (1997). Introduction: Theory and practice in critical discourse analysis. In L. Saha (Ed.), International encyclopedia of the sociology of education (pp. 1-11). Elsevier Science Limited.

Manitoba Council on Post-Secondary Education. (2007). The consultation on improving post-secondary outcomes for First Nations and Metis students in Southern Manitoba. Bear Spirit Consulting: Canadian Electronic Library (Firm).

Manitoba Education, Citizenship and Youth. (2005). When words are not enough: Precursors to threat; an early warning system for counselors. https://www.edu.gov.mb.ca/k12/specedu/ guidance/pdf/When_Words_Are_Not_Enough.pdf

Manitoba Education and Training. (2014a). Safe and caring schools: Taking actionagainst bullying. https://www.edu.gov.mb.ca/k12/docs/support/taking_action/document.pdf

Manitoba Education and Training. (2014b). Safe and caring schools: A resource for equity and inclusion in Manitoba schools. http://www.edu.gov.mb.ca/k12/safe_schools/mygsa/full_ doc.pdf

Manitoba Education and Training. (2015a). Towards inclusion: Supporting positive behaviours in Manitoba schools. https://www.edu.gov.mb.ca/k12/specedu/behaviour/behaviour_document.pdf

Manitoba Education and Training. (2015b). Safe and caring schools: Respect for human diversity policies. https://www.edu.gov.mb.ca/k12/docs/support/human_diversity/index.html

Manitoba Education and Training. (2017a). Safe and caring schools: A whole-school approach to planning for safety and belonging. http://www.edu.gov.mb.ca/k12/docs/support/whole_ school/index.html

Manitoba Education and Training. (2017b). Safe and caring schools, Provincial code of conduct: Appropriate interventions and disciplinary consequences. https://www.edu.gov.mb.ca/ k12/safe_schools/pdf/code_conduct.pdf

Manitoba Education and Training. (2018a). Manitoba's numeracy and literacy strategy.

Manitoba Education and Training. (2018b). It's our time: First nations education toolkit.

McLaughlin, J. R, \& Miller, T. W. (2008). Prevention of school violence: Directions, summary and conclusions. In J. R. McLaughlin \& T. W. Miller (Eds.), School violence and primary prevention (pp. 431-444). Springer.

Millei, Z., \& Petersen, E. B. (2014). Complicating 'student behaviour': Exploring the discursive constitution of 'learner subjectivities'. Emotional and Behavioural Difficulties, 20(1), 2034.

Noddings, N. (2002). Educating moral people: A caring alternative to character education. Teachers College Press.

Noguera, P. (2003a). City schools and the American dream. Columbia University.

Noguera, P. (2003b). Schools, prisons, and social implications of punishment: Rethinking disciplinary practices. Theory Into Practice, 42(4), 341-350.

Rankin, J., Rushowy, K., \& Brown, L. (2013, March 22). Toronto school suspension rates highest for black and aboriginal students, Toronto star. https:/www.thestar.com/news/ gta/2013/03/22/toronto_school_suspension_rates_highest_for_black_and_aboriginal_students.html

Roher, E. (2007). Will the new safe schools legislation make Ontario schools safer? Education Law Journal, 17(2), 203-221.

Rydell, A. (2010). Family factors and children's disruptive behaviour: An investigation of inksbetween demographic characteristics, negative life events and symptoms of ODD and ADHD. Social Psychiatry and Psychiatric Epidemiology, 45(2), 233-244.

Schick, C., \& St. Denis, V. (2007). Aboriginal education with anti-racist education: Building alliances across cultural and racial identity politics. Canadian Journal of Education, 30(4), 1068-1092.

Shevalier, R., \& McKenzie, B. A. (2012). Culturally responsive teaching as an ethics- and carebased approach to urban education. Urban Education 47(6), 1086-1105. 
Stein, M. (2003). Bullying or sexual harassment? The missing discourse of rights in an era of zero tolerance policies. Arizona Law Review, 45(1), 783-1127.

Swadener, B. B., \& Lubeck, S. (1995). Children and families "at promise": Deconstructing the discourse of risk. SUNY Press.

Swadener, B. B, Peters, L., \& Gaches, S. (2013). Taking children's rights and participation seriously: Cross-national perspectives and possibilities. In V. Pacini-Ketchabaw \& L. Prochner (Eds.), Resituating Canadian early childhood education (pp. 189-210). Peter Lang.

Thomas, G., \& Loxley, A. (2007). Deconstructing special education and constructing inclusion ( 2nd ed.). McGraw Hill.

Todd, S. (2003a). Learning from the other: A question of ethics. In S. Todd (Ed.), Learning from the other: Levinas, psychoanalysis, and ethical possibilities (pp.1-17). University of New York Press.

Todd, S. (2003b). Where are ethical possibilities? In S. Todd (Ed.), Learning from the other: Levinas, psychoanalysis and ethical possibilities (pp.140-148). University of New York Press.

United Nations. (2006). Convention on the rights of persons with disabilities. https://www. un.org/disabilities/documents/convention/convoptprot-e.pdf

VanDijk, T. (1989). Structures of discourse and structures of power. Annals of the International Communication Association, 12(1), 18-59.

Wall, J. (2008). Human rights in light of childhood. International Journal of Children's Rights, 16(1), 523-543.

Winnipeg Free Press Editorial Board. (2018, January 11). Crossover kids need innovative intervention. Winnipeg Free Press. https://www.winnipegfreepress.com/opinion/editorials/ crossover-kids-need-innovative-intervention-468734663.html

Winton, S. (2012). From zero tolerance to student success in Ontario, Canada. Educational Policy, 27(3), 467-498. 